\title{
O sol ofuscante de Hilda Hilst e Georges Bataille
}

\author{
Aline Leal Fernandes Barbosa ${ }^{1}$
}

Dever da lucidez: alcançar um desespero correto, uma ferocidade apolínea.

Emil Michel Cioran

Se olharmos para o sol por algum tempo - digamos, a metade de um minuto - o resultado disso é que uma massa escura se forma diante dos olhos e se espalha até tomar conta do cérebro. É um efeito temporário esse, e aqui descrito de forma não científica. Mas, de fato, um tipo de cegueira momentânea, estupor da visão obscurecida, traz uma experiência sensorial que pode gerar reflexões filosóficas. O sol, essa estrela alçada a astro, grande provedor da luz e do calor na terra, esfera ofuscante que aquece e queima, ilumina e cega.

"Se a despeito de tudo o fixarmos com bastante obstinação, isto supõe, pelo contrário, uma certa loucura e a noção [de Sol] altera o seu sentido porque, com a luz, a produção deixa de surgir e surge o resíduo", discorre Bataille no ensaio "Sol apodrecido"; ${ }^{2}$ ou seja, "a combustão que é psicologicamente muito bem expressa com o horror libertado por uma lâmpada de arco incandescente" (Bataille, 2007, p. 83). Esse resíduo que fica é o rastro da atitude louca, transgressiva, de nos aproximar daquilo de que deveríamos nos afastar. A lâmpada de arco incandescente é o resultado de luz e sombra daqueles que desafiaram os limites do possível da própria organicidade.

O resíduo fruto dessa ação temerária é a própria materialização, concretude do impossível da ação. Algo que dela resta do enfrentamento da impossibilidade de visualização. Sua intensidade sobre a organização dos corpos instala a novidade no tocante à ordem do vivido. Coisa que escapa da órbita dos olhos e que, em sua extrema potência de visibilidade, apresenta na mesma medida seus efeitos contrários e deletérios. Trata-se aqui não do que os olhos deixaram de ver com o efeito de castração do sol, mas daquilo que eles, apesar ou em função disso, viram. Incômodo

\footnotetext{
${ }^{1}$ Doutora em literatura, cultura e contemporaneidade pela Pontifícia Universidade Católica do Rio de Janeiro (PUC-Rio), Rio de Janeiro, RJ, Brasil. E-mail: alinelfbarbosa@ gmail.com

${ }^{2}$ Ensaio publicado originalmente no número 3 da revista Documents, em 1930.
} 
conviver com esse resíduo, porque difícil interpretá-lo, encaixá-lo, e vivê-lo acaba acompanhado do sentimento de angústia e dor.

Goethe, em seu Teoria das cores (1810), foi um dos primeiros a conferir às "pós-imagens" - isto é, às impressões residuais cromáticas e luminosas que se seguem ao contato dos olhos com uma fonte de luz ofuscante - o estatuto de "verdade ótica". Ao se debruçar sobre os círculos flutuantes diante dos olhos fechados, destacou a base subjetiva e fisiológica da visão. É o que Jonathan Crary conta em seu ensaio "The blinding light" (2000), em que analisa a fase solar do pintor J.M.W. Turner, sobretudo seu quadro Regulus, que faz referência à história do enviado romano para Cartago, onde foi detido e torturado até a morte por falhar em negociar a libertação de prisioneiros. ${ }^{3}$ Uma parte da punição de Régulus foi ter suas pálpebras arrancadas e forçado a olhar diretamente para o sol, cegando-se.

Esse sol olhado - ainda que sua manifestação mais completa deva ser de fato esse que brilha no céu - pode estar em outras figuras, para o indivíduo ou a sociedade. Para o personagem Pierre de Minha mãe (1966/1985), ${ }^{4}$ de Georges Bataille, este sol poderá ser a sua mãe, objeto de desejo e perdição, corrupção e prazer, maldição, vileza, desgraça, naufrágio, desespero, horror, ignomínia, provocação, baixeza, inconsistência - essas algumas palavras pinçadas da novela. Após a morte do pai, por quem Pierre nutria um sentimento de aversão, intensifica-se o relacionamento entre ele e sua mãe, que expõe sua atração pelo que há de mais baixo e o induz nesse

\footnotetext{
${ }^{3}$ O quadro de J.M.W. Turner conta a história de Marco Atílio Régulo (299 a.C.-246 a.C), político da gente Atília, da República Romana. No livro Os romanos para leigos, de Guy Bédoyère, encontramos a descrição da "lenda de Marco Atílio Régulo": "A história de Marco Atílio Régulo é ficção, mas foi inventada para ajudar a criar a imagem romana de honra e autossacrifício. A história dizia que Régulo estava conduzindo o exército romano no norte da África. Em 255 a.C., os cartagineses destruíram seu exército e o capturaram. Enviaram Régulo de volta a Roma para apresentá-los com os termos de paz dos cartagineses, na condição de que, se os romanos recusassem, ele voltaria para Cártago. Régulo voltou a Roma e fez um discurso tão provocativo para rejeitar as condições de paz dos cartagineses que, naturalmente, os romanos não aceitaram os termos. Mas Régulo manteve sua promessa, voltou a Cártago e foi torturado e morto." (Bédoyère, 2013, p. 208). Ao que tudo indica, a tortura infligida a Régulo, que teria tido as pálpebras cortadas e sido rolado morro abaixo dentro de um barril cheio de pregos, é, na verdade, ficção da propaganda bélica romana, e Régulo provavelmente teria morrido numa prisão da África.

${ }^{4}$ Ma mère é um romance póstumo, publicado em 1966, na França, pelos amigos de Bataille. É considerado um prolongamento inacabado de Madame Edwarda, publicado em 1941 sob o pseudônimo de Pierre Angelique. Ao que tudo indica, tratava-se de um projeto de realizar uma trilogia chamada Divinus Deus. Ma mére, então, estaria situada entre Madame Edwarda e Charlotte d'Ingervilles, também publicada após a morte de Bataille.
} 
caminho de transgressão que ela trilha. Em determinado momento, ela diz: “- Sua mãe - me disse ela - deverá desencaminhá-lo" (Bataille, 1985, p. 50).

Toda essa novela, como toda a ficção de Bataille, desenvolve-se nesse impulso erótico, de libertinagem, alheamento, marginalidade, ruptura. Está aí o foco da vida, do prazer: "o prazer só começa no momento em que o verme está no fruto. Apenas quando nossa felicidade vem carregada de veneno ela é deleitável" (Bataille, 1985, p. 63). Inunda-se de prazer na mesma medida em que ruma em direção ao abismo. Iniciase assim uma busca pela própria desgraça, em que reside alguma verdade, "o único bem digno desse nome, o único que não pode enganá-lo" (Bataille, 1985, p. 77).

Pierre lembra-se da frase lapidar de La Rochefoucauld (1613-1680): "'nem o sol nem a morte podem ser olhados fixamente'... Aos meus olhos, a morte não era menos divina que o sol, e minha mãe nos seus crimes estava mais próxima de Deus do que tudo que eu havia entrevisto pela janela da Igreja" (Bataille, 1985, p. 44). Sol, morte, Deus, mãe... Reúnem-se aqui os equivalentes que reinam em sua duplicidade e soberania. Geradores inesgotáveis de energia, absolutos no dispêndio dessa energia em direção à humanidade, absolutos no ato de jorrar. Fonte generosa e também corrosiva, provedora e castradora.

A noção de crime também aparece quando se trata de desviar-se da conduta permitida, como vemos em Minha mãe. Investe-se em uma vivência perigosa, aquela que fatalmente levará à maldição e à desgraça, mas ela é a única possível para os seres atormentados pela visão do horror; também o crime uma forma de busca intensa, anseio pela interrogação, desejo de transgressão. A transgressão é aquela dos corpos delimitados, atingidos pela faca, o sangue, o fluido, o sexo, a libertinagem, o crime, o sacrifício. Se crime é uma noção que se desenvolve social e historicamente, está sempre em rel(ação) de corte, ruptura - transbordamento em face daquilo que deseja ser controlado. E a literatura e as artes são potencialmente criminosas, porque trabalham com uma contrapossibilidade, por exemplo, na exposição da artificialidade em que se habita, no apontamento de impossibilidades possíveis, no atravessamento de limites éticos e estéticos e, portanto, arte e literatura são também sujeitas a condenações.

Bataille afirma: "a vida humana não pode em caso algum ser limitada aos sistemas fechados que lhe são destinados em concepções judiciosas" (Bataille, 2013, p. 32). De fato, ela só começa com o déficit desse sistema: 
do que se libera, do que escoa no processo de insubordinação das forças ordenadas e reservadas, de modo que a vida residirá em seu transbordamento. $\mathrm{O}$ crime representa em relação à lei o que o dispêndio representa em relação às obras de crescimento, sua qualificação subversiva. Bataille vai insistir na interdependência dos movimentos de conservação e dissipação, engrenagem fundamental da vida humana: "Os homens asseguram sua subsistência ou evitam o sofrimento, não porque essas funções determinem por si mesmas um resultado suficiente, mas para ter acesso à função insubordinada do dispêndio livre" (Bataille, 2013, p. 33). Resta-nos, assim, desfrutar dos variados prazeres do crime, porque daí também advém a ordem necessária.

Em Minha mãe, destaco a seguir (figura 1) um trecho grifado por Hilda Hilst em seu exemplar: "Na solidão em que penetrei, as medidas deste mundo, se subsistem, é para manter em nós um sentimento vertiginoso de desmedida: essa solidão é Deus" (Bataille, 1985, p. 39).

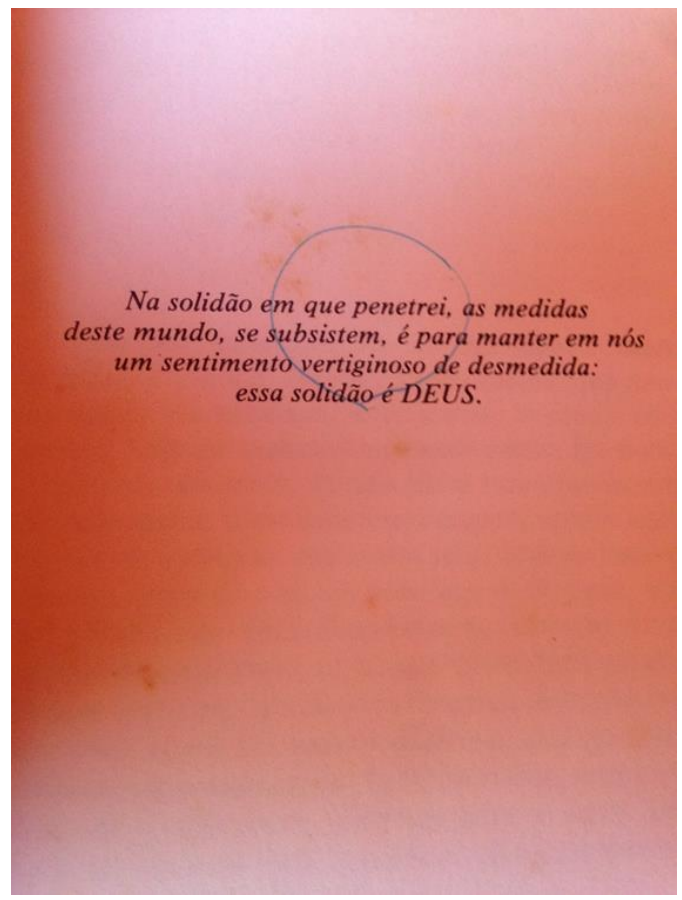

Figura 1 - Grifo de Hilda Hilst no seu exemplar de Minha mãe, de Bataille 
No prefácio ao livro de poesia Poemas malditos, gozosos, devotos (1984/2005), de Hilda Hilst, em que a poeta interpela Deus, Alcir Pécora discorre a respeito dos mistérios dolorosos a que "se dispõe o poeta, que reconhece perfeitamente que o pensamento de Deus é, em essência, uma entrega à mais apavorante solidão. Isto é, pensar em Deus é, no limite, compor na própria carne um discurso de ausência, de desejo sem nenhuma correspondência" (Hilst, 2011, p. 12). Pécora destaca aqui uma relação de não reciprocidade, transcendência, falta de esperança em uma comunicação possível aliada ao intenso desejo e movimento de comunicação, apontando para a própria dinâmica do erotismo: ele é ao mesmo tempo transgressão e revelação do interdito e, além disso, encontro com a angústia, pois abala a ordem do vivido.

Se o sol, em sua energia absolutamente poderosa, soberana e inesgotável, parece situar uma relação de não reciprocidade conosco, porque tudo nos dá e nada pede em troca, estabelecendo uma noção de transcendência, não é necessariamente assim que se deve pensar essa relação. No prólogo do Assim falou Zaratustra, o profeta se retira para as montanhas e passa dez anos em uma caverna aberta acumulando a luz do sol. Um dia Zaratustra sai e faz um discurso para ele, em que ao mesmo tempo o louva e diz que ele não seria o sol se não tivesse a quem iluminar. Isso, mais as referências do lago e da montanha, e da águia e da serpente, já condensam simbolicamente o projeto poético/filosófico da obra: instaurar um pensamento da pura imanência, em que tudo se afeta reciprocamente, sem nenhuma instância transcendente, como as que, sob várias roupagens, guiaram a nossa tradição metafísica de civilização, cultura e valores. Esse prólogo espelha e sob certo aspecto inverte o sentido da alegoria da caverna de Platão, a grande instauração filosófica da transcendência, em que o sol é posto como símbolo da ideia de Bem, o princípio dos princípios, que transcende mesmo as formas transcendentes.

Deus perpassa aqui dinâmica semelhante, ser de luz e trevas, bondoso e temerário, provedor e assassino, comunicação e silêncio, via do corpo e do espírito. Deus esse sol a que se recorre incansavelmente, intenso desejo de busca e, no afã de comunicação com o divino, entra-se no campo do sacrifício. O sacrifício - instituição definida, verdadeira função social, como descreve Bataille - representaria a intenção de semelhança perfeita com um termo ideal através de alguma forma de (auto)mutilação, como um tirar para fora de si. Deus, ser fulgurante, que enche os humanos de 
estupefação, tem uma via de acesso a partir do sacrifício, porque nele "O deus, que é ao mesmo tempo o sacrificante, confunde-se com a vítima e por vezes até com o sacrificador. Todos estes elementos díspares, que entram nos sacrifícios vulgares penetram aqui uns nos outros e confundem-se" (Bataille, 2007, p. 107).

Essa busca pelo desconhecido toma a forma de uma ânsia por linguagem, talvez de uma correspondência mais satisfatória e ajustada, da palavra exata, ou senão uma corrupção dessa correspondência tão artificial que engana e frustra. Busca-se por um sentido porque nada fecha e nem deve fechar, mas a vivência consciente dessa dissolução apresentada como aporia - causa o sentimento de abandono. A ideia do engano e da impossibilidade do conhecimento gera o vazio e o desamparo. A obscena senhora D (1982/1993), relato de Hillé, uma mulher de 60 anos que decide viver no vão de uma escada e recusa sistematicamente o bom-senso de Ehud, seu marido recentemente falecido, começa assim:

Vi-me afastada do centro de alguma coisa que não sei dar nome, nem por isso irei à sacristia, teófaga, incestuosa, isso não, eu Hillé também chamada por Ehud A Senhora D, eu Nada, eu Nome de Ninguém, eu à procura da luz numa cegueira silenciosa, sessenta anos à procura do sentido das coisas (Hilst, 1993, p. 17).

Esse livro aparece com destaque na produção ficcional de Hilda Hilst: foi com ele que se inaugurou a edição das obras completas da autora pela editora Globo, organizada por Alcir Pécora, que considerou que aí se cruzavam os grandes temas da sua prosa de ficção. Para nós, $A$ senhora $D$ interessa o lançar-se no fluxo de consciência - que, nesse caso, adquire forma dialógica, uma conversa entre Hillé e Ehud - de uma personagem que tende ao transbordamento de sua existência, no limiar de um processo ao mesmo tempo de dessubjetivação e de autoconstrução, que redundará em seu devir-porca. O exercício ao qual Hillé se propõe é o de buscar esse resíduo - fruto do olhar para o sol em sua plena combustão, atitude transgressora de revelação - que será o aproximar-se da compreensão. Ehud insiste em que não há resposta, nem no vão da escada, nem no andar de cima, mas Hillé teima em buscá-la para talvez encontrá-la "no sopro de alguém, num hálito, num olho mais convulsivo, num grito, num passo dado em falso, no cheiro quem sabe de coisas secas, de estrume, um dia um dia um dia" (Hilst, 1993, p. 35). Também Hillé "buscava nomes, tateava cantos, vincos, 
acariciava dobras, quem sabe se nos frisos, nos fios, nas torçuras, no fundo das calças, nos nós, nos visíveis cotidianos, no ínfimo absurdo, nos mínimos, um dia a luz, o entender de nós todos o destino, um dia vou compreender, Ehud" (Hilst, 1993, p. 35).

Hillé, personagem marcante de Hilda Hilst; a senhora D de derrelição, desamparo e abandono. Hillé e suas máscaras. Hillé e seu devir-porca, abjeta. Hillé e seu espírito de não vizinhança. A narrativa se passa um ano após a morte de Ehud, ainda assim, ela é toda um diálogo com ele, num impasse entre a vontade de expansão de Hillé e a de contenção de Ehud, essa uma conversa em fluxo contínuo, com falas sobrepostas, sem marcação do emissor, com períodos abertos, poucos sinais delimitadores do discurso escrito. Hillé não é só Hillé, é também Senhora D, mulher-porca, sapa. Hillé é polifônica, porque nela soam várias vozes: a de Ehud, as da vizinhança, a do menino-porco. Ela substitui os peixes do aquário por peixes de papel pardo, porque não suporta coisa-viva, mesmo o corpo e suas satisfações. E no movimento de afastar-se do que a linguagem não pode alcançar, Hillé diz: "não venha Ehud, não posso dispor do que não conheço, não sei o que é corpo mãos boca sexo, não sei nada de você, Ehud" (Hilst, 1993, p. 39).

\section{Obsceno sol}

No ensaio "A mutilação sacrificial e a orelha cortada de Van Gogh" (figura 2), 5 Georges Bataille relata a história de Gaston F., um desenhador de bordados que decepou o indicador esquerdo com os próprios dentes. Atraído pelos raios do sol, fixou nele seu olhar e acreditou receber o comando de seção. Parece que o automutilador havia lido uma biografia de Van Gogh em que aprendera que o pintor, em um ataque de loucura, havia metido a faca na própria orelha, embora, como aponta Bataille, "quando uma decisão intervém com a violência necessária para se cortar um dedo, escapa por completo às sugestões literárias que tenham podido antecedê-la; e a ordem que os dentes tão repentinamente tiveram que acatar deve surgir como uma necessidade que ninguém conseguiria resistir" (Bataille, 2007, p. 95).

\footnotetext{
${ }^{5}$ Ensaio publicado no número 8 da revista Documents, em 1930.
} 


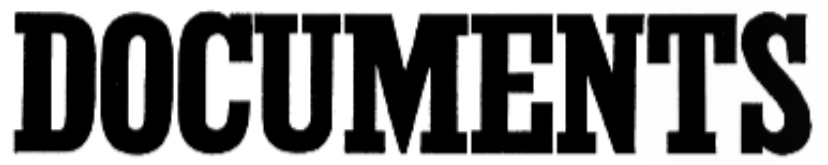

\section{ARCHÉOLOGIE BEAUX-ARTS ETHNOGRAPHIE VARIÉTÉS}

Magazine Illustré

paralssant dix tois par an

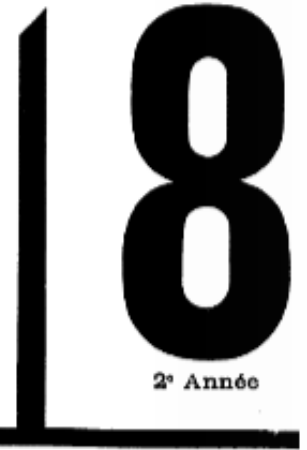

Heinrich EHL. L'beare do saissaace de l'art européen océdental. - Gearges BATAIIE, La mutilation sacrificielle et l'oreille coupie de Vincent Van Gozh. - Michel LEIRIS, Lo " caput mortuan" ou la femme de I'alchimiste. - Jean BOURDEMLETTE, Franx Xaver Messerschmidt. - Zdeako REICH, Le massaere des parcs, - Cart EINSIEIN, L'ealance nbalithique [Hans Arp]. - Une legende des Iroguois a la Grabde Tâte.

Chrenique par C. Bataille, Maurice Leenbardt, Jacques Prévert.

Photographias de J-A. Boifferd ot de I'Institut de Mierographie.

PARIS,

106, B $^{d}$ Saint-Germain (VI)

Figura 2 - Capa da edição de número 8 da revista Documents, em que consta o artigo de Bataille.

Fixar o sol como pulsão suicida, outrora foi considerado por alienistas como sinal incurável de loucura. O filósofo René Descartes (1596/1650) acreditava que o sol, se olhado sem mediação ou representação produziria um atordoamento semelhante à loucura (Crary, 2000, p. 23). Em 1889, no asilo de alienados de Saint Rémy, Van Gogh ergue os olhos para o "sol em toda a sua glória", expressão que ele emprega em uma carta ao irmão, época em que sua obsessão solar chega a um ponto culminante (Bataille, 2007, p. 96). Em julho de 1890, depois de sair de Saint-Rémy, Van Gogh comete suicídio. Bataille apresenta também relatos de enucleação, como a necessidade de tirar 
algo para fora de si. Fixar o sol como a própria atitude transgressora que enfrenta o comando do olho de desviá-lo. Ousar fixá-lo, ousar queimarse, ousar cegar-se, uma forma de (auto)sacrifício.

Não é imediato associar Georges Bataille ou Hilda Hilst a autores solares, pelo menos não no sentido mais corrente que se tem da ideia de sol. Aliás, a tendência é que a eles sejam atribuídos às trevas, às sombras, ao lado obscuro da vida, que desejaram perscrutar a fim de se deparar com algum resíduo, alguma lucidez. São autores assombrados, do horror, do desamparo, das margens. Suas obras estão marcadas pela postura transgressora, por uma ofensa aos valores, ao bom gosto, às categorias, à razão. Estão eles menos próximos de Apolo - deus solar da forma - que de Dionísio. Em "O coice do burro", Michel Surya, biógrafo de Bataille, comenta em relação à Mutilação sacrificial e a orelha cortada de Van Gogh: "Só os moralistas dizem que o horror deve ser combatido. Bataille faz pior: conta-o em pormenor e deixa-se, complacentemente, fascinar por ele; uma lucidez de olhos abertos que fixam o sol" (Surya, 1994, p. 18).

Somente através do horror se poderá escapar à pobreza das experiências realistas e alcançar o sentimento de verdade, fórmula que deve valer tanto para a ficção quanto para a vida. Bataille afirma: “o horror teve por vezes em minha vida uma presença real. Também é possível que, mesmo alcançado na ficção, somente o horror tenha me permitido escapar da sensação de vazio da mentira" (Bataille, 1962, p. 9, tradução nossa).

Em Hilda Hilst, por sua vez, o horror é associado à obscena lucidez: "e o que foi a vida? uma aventura obscena, de tão lúcida" (Hilst, 1993, p. 71), diz Hillé. Schøllhammer (2007, p. 82) destaca: “Obscenus: tudo aquilo que acontece além da encenação dos sentidos", palavras, discursos, situações tipo sol do meio-dia, que desagradam o olhar e que conviriam antes castrar que ter de lidar com elas.

Obscenidade e lucidez como contraponto ao sentido dado - da cena -, contraponto à linguagem como sistema fechado do sentido próprio, obscenidade e lucidez como poesia. Alcir Pécora (2005) trata do rompimento dos pactos na obra hilstiana, no sentido de desmontagem, decomposição da escrita, a fim de descobrir as partes do texto que estão dissimuladas e nos interditam. Sonia Purceno indica a obscenidade como marca das violações que atiçam as possibilidades do artista: “O obsceno, portanto, será tratado como objeto de perseguição; aquilo que $\mathrm{HH}$ e os escritores criados por ela desejavam esgotar a fim de exorcizar o 'fracasso' no 'excesso de lucidez' e 
estraçalhar o que se encena" (Purceno, 2005, p. 65), entendendo que obscenidade e invenção literária são movimentos cúmplices.

Georges Bataille e Hilda Hilst parecem encenar um obsceno sim, ${ }^{6}$ no sentido em que em suas obras abstiveram-se em larga medida de censuras temáticas ou formais, trouxeram à cena tudo o que se esperava que dela ficasse de fora (Purceno, 2005, p. 65), tudo abarcaram sem imporem-se restrições de ordem moral, autônomos em relação a tais pressupostos, considerando ser essa a dicção própria do artista, no desvelamento das estruturas limitadoras da linguagem, das máscaras proliferantes e cambiáveis socialmente, dos pactos sociais que dissimulam naturalidade, afirmando o impossível de que Bataille fala, estado próprio da poesia. No trecho a seguir, em uma entrevista publicada em 1975 n'O Estado de S. Paulo, Hilda Hilst comenta:

Há pessoas que tratam a carne como outros tratam o ouro, às escondidas. Escolhi para meus textos o tratamento oposto. Samuel Beckett ${ }^{7}$ na sua peça Dias felizes escreve: "Eu não posso dizer mais; diz-se o que se pode". Prefiro dizer: Quero falar tudo nos meus textos e posso dizer ainda mais. Faço perguntas possíveis a mim mesma: se eu falasse com a voz do mundo, como falaria? Se eu falasse com a voz dos ancestrais (que representa o sangue e o sêmen dentro de mim) haveria a refulgência de uma nova voz? É preciso tentar tudo, experimentar tudo. Talvez assim a verdade, a resposta, seja encontrada (Diniz, 2013, p. 34). ${ }^{8}$

So much I want to say, ${ }^{9}$ ecoa a voz da artista plástica Mona Hatoum em sua obra homônima (figura 3), enquanto mãos calam fisicamente a

\footnotetext{
${ }^{6}$ Em trecho do documentário Hilda (Humana) Hilst (2002), quando questionada sobre o que, na vida, não havia feito, em tom claro de deboche, Hilda Hilst, já uma senhora, responde: "Foder com uma mula eu nunca fodi". Hilda (Humana) Hilst é um documentário produzido em 2002 por alunos da disciplina "A Mensagem Videográfica: Problematização e Realização", ministrada pelo professor Paulo Bastos Martins, do Departamento de Multimeios do Instituto de Artes da Universidade Estadual de Campinas (Unicamp).

${ }^{7}$ Embora pareça aqui que Hilda Hilst esteja se afastando de Beckett, muitos estudos apontam para a proximidade entre esses autores. No ensaio "Da ficção", de Leo Gilson Ribeiro (1999), essa afinidade é elaborada.

${ }^{8}$ Em Cartas de um sedutor, no pequeno conto "Triste", apresenta-se uma construção parecida a essa. O personagem do conto aparece na cidadezinha, não se sabem o nome, de onde veio, e ele fala uma única frase: "nem tudo pode ser arrumado.". Até que, em um dia chuvoso, ele diz outra coisa: "nem tudo pode ser arrumado, arruma-se o que se pode" (Hilst, 2014, p. 186).

${ }^{9}$ O vídeo So much I want to say, de 1983, consiste em uma série de imagens still, trocando a cada 8 segundos, em que aparece a face da artista em close-up com um par de mãos masculinas
} 
sua boca. Tirando aqui o contexto dessa obra política, imaginamos a frase saindo da boca de um semblante já envelhecido de Hilda Hilst. So much I want to say, diria a senhora, autora de 40 livros entre poesia, teatro e prosa, que, embora tenha parado de escrever quatro anos antes de sua morte, afirmando que já havia escrito tudo, assumiu como missão a escrita, construindo uma casa - a Casa do Sol - para esse propósito, fazendo desse exercício uma investigação da vida em todas as suas relações, negando os instrumentos de censura que incorrem sobre os indivíduos, sobretudo às mulheres de sua época, fazendo pouco das possibilidades para encetar os impossíveis.

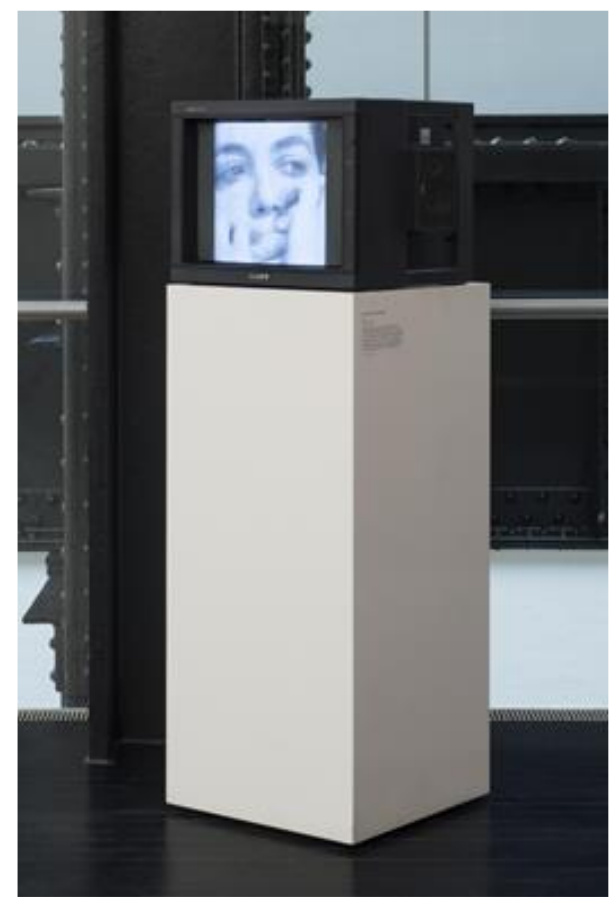

Figura 3 - Instalação de So much I want to say, de Mona Hatoum.

Fonte: Tate Gallery.10

sufocando sua boca e a impedindo de falar. Enquanto isso, sua voz repete infinitamente o título da obra. Hatoum nasceu em 1952, em Beirute, no Líbano, e foi para Londres em 1975, como exilada da guerra libanesa.

${ }^{10}$ Disponível em: <http://www.tate.org.uk/art/artworks/hatoum-so-much-i-want-to-say-t07536>. 

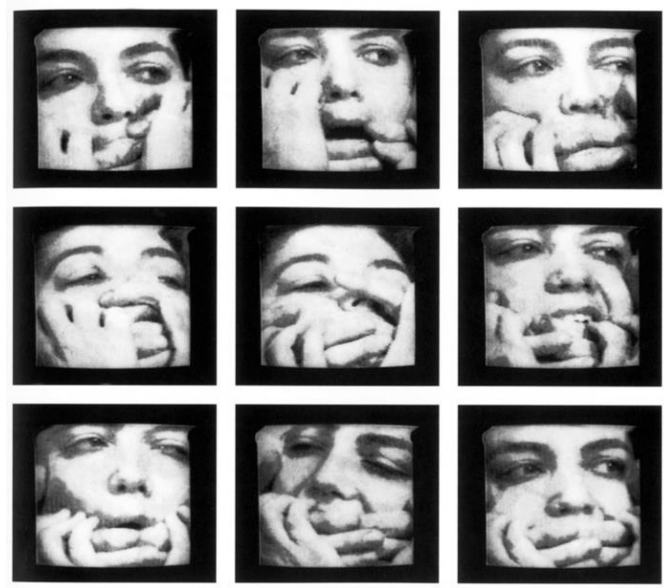

Figura 4 - Detalhe da série de stills de So much I want to say, de Mona Hatoum. Fonte: X-tra. ${ }^{11}$

Expondo da carne a carne, e não a banhando em ouro, fazendo-a produto, moeda de troca, ou tão simplesmente higienizando-a de sua futura podridão. Hilda Hilst em sua vivência do erotismo como uma "experiência ligada à vida, não como objeto de ciência, mas paixão, mais profundamente, uma contemplação poética" (Bataille, 2013, p. 31), como Bataille o definiu em $O$ erotismo. Georges Bataille e Hilda Hilst, autores que ousaram fixar esse sol, encarar a morte, dialogar com Deus... deitarse com a mãe? O tabu original.

\section{Arriscar queimar-se}

Um sol por demais incandescente: Lori Lamby, capaz de deixar inconformados leitores que se imaginariam livres de julgamentos morais diante do objeto literário. Humberto Werneck, em artigo publicado pelo Jornal do Brasil, em 1990, reuniu algumas reações à época de sua publicação:

Se o objetivo era chocar, foi alcançado em cheio, a julgar pela reação das pessoas a quem mostrou os originais. Um amigo, ela conta, o pintor Wesley Duke Lee, achou O caderno rosa "um lixo absoluto". Outro, o médico José Aristodemo Pinotti, ex-secretário da Saúde do estado de São Paulo, considerou que "uma poetisa

\footnotetext{
${ }^{11}$ Disponível em: <http://x-traonline.org/article/closer-exposure-2009-and-4/>.
} 
nunca deveria enveredar pelo pornô". A escritora Lygia Fagundes Telles, com quem troca confidências e produção literária desde os anos 1950, admite que ficou "meio assustada, aturdida". O editor Caio Graco Prado, da Brasiliense, gostou do que leu, mas, temendo o escândalo, não se aventurou a publicar. Não tive coragem, confessa. Mesmo o crítico Leo Gilson Ribeiro, há muitos anos uma voz solitária na defesa de Hilda, não pareceu entusiasmado com a mudança de rumos (Werneck, 2016, p. 245-246).

Personagem de 8 anos, Lori Lamby fala de toda a sua experiência sexual a partir de um repertório infantil. O universo da criança atravessado por essa experiência é contado com a ingenuidade da descoberta, em um trabalho de aproximação de universos a princípio afastados, portanto o estranhamento e o desconforto que causam, a sensação de desencaixe. A linguagem conduzida pela criança é como se tratasse de algo que ela desconhece, a criança descobrindo o mundo a partir de um repertório escasso, e avançando na captura dessa novidade com uma linguagem ainda selvagem, precária na elaboração de um mundo já cheio de significados. Insistimos então na hipótese de que a escrita, nos livros de Hilda Hilst, adquire um caráter investigativo da própria realidade, um trabalho de aproximação, toque, tato, contato em que linguagem e experiência fundem-se ora como acerto e estabilidade, ora como dissonância e abandono. Um exemplo: "Eu perguntei se o pau era a cacetinha, mas esse homem disse que não, que era pau mesmo. Eu peguei na coisa-pau dele e na mesma hora saiu água de leite" (Hilst, 2016, p. 19).

Diminutivos, associações pueris e originais, desconhecimento de vocabulário $^{12}$ dão o tom de inocência que possibilita colocar a personagem na situação de confronto com o desconhecido, um jogo que é construído a partir das ferramentas disponíveis à personagem,

\footnotetext{
${ }^{12}$ Em vários momentos Lori Lamby se vê em busca do significado das palavras. Um exemplo: - Lorinha, você tem a bundinha mais bonita que eu já vi, e eu já vi que você tem dois furinhos, duas covinhas em cima da bundinha, e isso é raro.

- O que é raro?

- Raro é quando pouca gente tem.

- O que, por exemplo?

- Dinheiro - ele disse - e os teus furinhos.

- Mas dinheiro é fácil.

- É fácil nada.

- Pra mim é fácil.

- É que você é predestinada.

Aí ficou difícil para ele explicar o que é predestinada (Hilst, 2016, p. 23).
} 
ressaltando o contraste entre o mundo da criança e o do sexo. Narrada por uma menina de 8 anos, a carga sexual de que se vale é potencializada à perversão, à situação de crime, pedofilia.

Diferentemente da novela batailliana Minha mãe, que tem no incesto a ideia clara de transgressão - e no que isso traz de angústia e prazer -, a narrativa de Lori Lamby está destituída de culpa no seu contar, pois os conceitos e códigos morais ainda não foram todos eles assimilados pela protagonista, que atravessa a experiência, de um lado, pela perspectiva do corpo e seus modos de sentir, do outro, pela perspectiva do capitalismo e seus modos de apropriação. Lori diz: "Ele perguntou me lambendo se eu gostava do dinheiro que ele ia me dar. Eu disse que gostava muito porque sem dinheiro a gente fica triste porque não pode comprar coisas lindas que a gente vê na televisão" (Hilst, 2016, p. 12). E adiante: "mas a coisa de predestinada é mais ou menos assim: uns nascem pra ser lambidos e outros pra lamberem e pagarem. Aí eu perguntei por que quem lambe é que paga, se o mais gostoso é ser lambido. Então ele disse que com gente grande os dois se lambem e tem até gente que não paga nada nem pra ser lambido" (Hilst, 2016, p. 23).

Em uma das possibilidades de leitura desse texto desdobrável (caderno, diário, novela, paródia, sátira), Lori Lamby será personagem ficcional desse pai, escritor genial rejeitado pelo público, às voltas com seu editor - o tio Lalau -, que o pressiona a publicar "bandalheiras", a fim de tornar-se financeiramente viável. Alcir Pécora, em Por que ler Hilda Hilst?, aponta para esta possível chave de leitura:

nada barra definitivamente a suposição de que Lori seja apenas o nome do narrador-personagem criado pelo narrador-personagem do pai de Lori, gênio incompreendido, rendido à venalidade de Lalau, o editor. E isto pode seguir em várias direções, sacando-se narrador de dentro de narrador, caderno de dentro de caderno, sem que ao cabo dessa incontinência da imaginação uma instância se afirme como a única possível (Pécora, 2010, p. 25).

Sabemos que esse livro tem afinidades em relação à - pretensa guinada na escrita que Hilda Hilst estava realizando com o lançamento de sua trilogia erótica. Lançado em 1990, quando a autora tinha 60 anos, cansada de editores e leitores pouco afinados com sua obra, considerada rebuscada demais para o grande público e, portanto, impossibilitada de fazer parte do ć́rculo daqueles que ganham dinheiro com livros, desgostosa da pecha de ser uma escritora genial que não era lida, uma 
autora maldita, $\mathrm{HH}$ resolve fazer uma prosa declaradamente - e lançada midiaticamente, pode-se dizer - pornográfica, anunciando seu "adeus à literatura séria". Porém, já foi dito o quanto essa fase soa mais como uma extensão - ou o escancaramento - de uma escrita que já tende ao erotismo, e também o quanto essa tentativa de estreitar os laços com o público não resultou em uma literatura mais "fácil" ou "convencional" e, portanto, mercadológica, demonstrando que Hilst não parecia preocupar-se muito com esse provável leitor.

Sônia Purceno afirma que: "não há rupturas drásticas na obra de Hilda e que a tetralogia veio enfatizar questões fulcrais de sua produção que pode ser centralizada em A obscena senhora $D$ e em Com os meus olhos de cãa" (Purceno, 2010, p. 65). E Alcir Pécora observa: "a crueza desses textos não tem como efeito a excitação do leitor, a não ser que o leitor se trate (como me esforcei para imaginar certa vez), de um tarado lexical, de um onanista literário" (Pécora, 2010, p. 20), de modo que só quem tivesse uma tara semântica poderia se masturbar com os seus livros pornográficos. Mas Lori Lamby dá tesão? A depender da resposta, amplia-se ou se apazigua a autocondenação do leitor.

É claro que esse texto foi fortemente polemizado à época de sua publicação, e continuará sendo polêmico, porque transgride uma série de interditos absolutamente primordiais para a organização da nossa sociedade, protetores de uma ideia de civilização que progrediu até formalizar esse humano possível e atual. A criança, especialmente a menina, é colocada em situação que não condiz com o lugar a ela concedido, aliás, é uma agressão a esse lugar, bem como aqueles que são dispostos em torno dela atuam de forma a embaralhar os códigos estritos e escritos: Lori Lamby é incentivada e empresariada pelos próprios pais na atividade sexual, é detentora de desejo e prazer e está amplamente inserida em uma sociedade de consumo, que tem o dinheiro como principal mediador das relações. Lori Lamby foi abusada e explorada sexualmente, é vítima desse mundo de adultos e suas perversões, pedofilia e proxenitismo? O caderno de Lori Lamby é, por si só, criminoso enquanto publicação? Seus leitores são sádicos? Essas questões foram colocadas criticamente à obra, ressaltando aí o quanto a literatura - a arte -, embora realize um contraponto à vida real, à sociedade, ao criar um mundo autônomo desses pressupostos, será sempre lida por esse indivíduo - ou corpo social - que habita o mundo real da ordem, do qual certos princípios são inegociáveis. 


\section{Sol incandescente}

Então, qual será o limite do "obsceno sim"? Se a obscenidade está relacionada à exposição do que deveria permanecer à sombra, qual será o limite suportável desse dar a ver, qual a fronteira entre o "obsceno sim" e o "repressor não"? Em entrevista ao crítico Leo Gilson Ribeiro, Hilda Hilst fala de uma conduta literária que não pode deixar de ser "entranhadamente ética", isso porque o motor de todo escritor roda no sentido de não pactuar como o que nos é imposto como mentira circundante: "O escritor é o que diz 'Não', 'Não participo do engodo armado para ludibriar as pessoas'” (Diniz, 2013, p. 56), fazendo, portanto, da linguagem e da sintaxe uma ferramenta política (contra a polícia). Não pactuar, em Hilda Hilst e em Georges Bataille, será um gesto de liberdade. No entanto, em entrevista a Léo Gilson Ribeiro, ${ }^{13}$ a própria Hilda Hilst admite que há um limite - ético - para essa abertura:

Eticamente algum escritor, alguma pessoa, pode assumir a tremenda responsabilidade de romper os limites que o outro aceitou, ou porque lhe foram impostos de fora ou porque ele se arrumou diante dessa conciliação com a opressão externa e o condicionamento interno de que foi vítima? Revelar ao outro que ele pode muito mais e pode ser ele mesmo com uma liberdade total de qualquer tipo de repressão política, econômica, sexual, religiosa, psicológica etc., eu me pergunto, não pode levar uma pessoa à morte, à loucura sem retorno? (Diniz, 2013, p. 57).

Trata-se de uma questão de sobrevivência, na medida do que é tolerável em termos de ruptura das fronteiras da constituição do real histórica e socialmente definido. A responsabilidade do escritor, portanto, repousa em uma linha de caráter vertiginoso, oscilando entre transgredir os tabus morais artificialmente impostos e limitadores da experiência e preservar os limites que possibilitam a experiência, como concepção humana. O escritor, imbuído dessa tarefa, flerta então constantemente com a linha da transgressão - logo está nessa corda-bamba - redefinindo ou subtraindo os limites éticos

\footnotetext{
${ }^{13}$ Entrevista intitulada "'Tu não te moves de ti', uma narrativa tripla de Hilda Hilst", originalmente publicada no jornal $O$ Estado de S. Paulo, em 16 de março de 1980.
} 
mediadores das relações sociais. O escritor parece, portanto, apontar para a experiência do impossível de que Bataille trata.

Ao propor uma elaboração literária - temática e operatória - do impossível, Bataille realiza uma investigação radical sobre os limites da experiência humana a fim de identificar as chaves de acesso para o que nos une profundamente. A questão é saber se esse ser limitado e utilitário será capaz de restituir sua continuidade essencial, aquela que foi sufocada sob o triunfo da racionalidade - e moral - ocidental. Nesse propósito, Bataille vai se interessar por experiências fundamentais como o erotismo, o sagrado, a morte. Mas é importante ressaltar que essa empreitada está fadada ao fracasso, visto que o impossível é negado na medida dos limites intransponíveis do homem (ser limitado, descontínuo), legando à literatura - e ao escritor - o movimento vertiginoso entre o possível e o impossível.

No ensaio "Pornografia e obscenidade", D. H. Lawrence ensaia uma resposta à censura de seus livros e pinturas, e realiza uma análise das questões do sexo e da liberdade em uma sociedade marcadamente moralista. Aí Lawrence anuncia o que seria a verdadeira libertação do ser das perversas mentiras sociais: "Acima de tudo a libertação do eu, da mentira do eu, da mentira da importante ascendência do eu" (Lawrence, 1929/1984, p. 9). Trata-se, assim, de sair do círculo vicioso do eu, da masturbação do eu, do autocativeiro, da consciência de si próprio. Trata-se de trazer à luz do dia o "segredinho reles", o segredinho sujo estimulado apenas pela pornografia autorizada e, em seu lugar, dar relevância aos impulsos sexuais criadores. Nesse sentido, Lawrence (1984, p. 8) afirma:

Um homem deve ter a consciência necessária para conhecer os seus próprios limites e pressentir a existência de algo que o ultrapassa. Aquilo que consegue ultrapassar-me é o impulso da vida no interior de mim próprio, vida que me obriga a esquecer de mim próprio e ceder ao violento, mas só meio consumado, impulso que me leva a destruir a grande mentira do mundo e a criar um novo mundo.

O impulso transgressor que corrompe as barreiras do eu e o situa para um além de si está ausente, segundo Lawrence, da pornografia moderna, dos best-sellers, interessados apenas em excitar furtivamente, provocar uma estimulação "sub-reptícia". Por sua vez, as grandes obras que transformaram o mundo têm a grandeza do apelo sexual não 
dissimulado, sua violenta potência libidinal: "O sexo é um fortíssimo, benéfico e necessário estimulante da vida humana, e todos ficamos reconhecidos ao sentir-lhe o quente e genuíno fluxo que em nós penetra como uma espécie de sol" (Lawrence, 1984, p. 3).

Voltamos então ao sol. Ao seu encontro dramático com os olhos. Na pintura de Turner, a posição de Régulus é coincidente com a dos observadores do quadro. Com ele, olhamos sem piedade para o sol, e a luz que define os contornos da visão será a mesma que provoca a indistinção absoluta, na fusão entre sujeito e objeto, sol, olho e mundo e, em última instância, também entre ser e divindade. Como Régulus, estamos no limiar entre o brilho total e a escuridão absoluta. Entretanto, como aponta Jonhathan Crary no já citado ensaio "The blinding light", não se trata de cegar-se como o término final da visão, mas, em vez disso, como abertura para a reversão desse mundo existente e os hábitos visuais que o sustentavam. Evoca-se, assim, o tema do apocalipse, não no sentido de cataclismo ou destruição, mas no seu sentido paralelo de revelação e advento para um novo mundo. Crary (2000, p. 25, tradução nossa) observa: "A arte de Turner é um dos lugares cruciais dentro da modernidade em que a aspiração para expandir radicalmente os limites da experiência sensorial encontra paralelo com o desdobramento das transformações sociais, políticas e tecnológicas".

Assim, enfrentar o sol, arriscar queimar-se, será o próprio imperativo ético que balizará a conduta do escritor, na inscrição de inimagináveis, na ampliação de possíveis, na introdução do caos em uma ordem vigente e no próprio processo de transformação, no ultrapassamento e libertação do eu. Essa conduta, por sua vez, estará alinhada com a conduta do obsceno, na medida em que faz caírem as máscaras socialmente impostas para revelar o que se encontra por baixo da carcaça imaculada do indivíduo.

Bataille, em a História de ratos (1988, p. 40) diz: "Só gosto de viver desde que me queime (não me faltava nada, querer durar)", inserindo aí a questão temporal. Podemos pensar também em Hilda Hilst a mirar o sol sem proteção, lançando-se destemidamente em uma experiência heliotrópica, uma investigação dos limites dos enquadramentos visuais. Mas, afinal, de que sol se trata? É, pois, preciso encarar esses luminares, privilegiar o instante escaldante ao futuro redentor. Enfim arriscar queimar-se, amar mesmo o calor desta chama. 


\section{Referências}

BATAILLE, Georges (1962). L'impossible. Paris: Minuit.

BATAILLE, Georges (1985). Minha mãe. São Paulo: Brasiliense.

BATAILLE, Georges (1987). O erotismo. Porto Alegre: L\&PM.

BATAILLE, Georges (2007). O ânus solar. Lisboa: Assírio e Alvim.

BATAILLE, Georges (2015). A literatura e o mal. Belo Horizonte: Autêntica.

BATAILLE, Georges (1988). História de ratos (diário de Dianus). Lisboa: Hiena.

CRARY, Jonathan (2010). The blinding light. In: CRARY, Jonathan; FRANCIS, Mark (Org.). J MW Turner: the sun is God. Liverpool, UK: Tate Publishing. p. 18-27. Catálogo de exposição.

DINIZ, Cristiano (Org.) (2013). Fico besta quando me entendem. São Paulo: Globo.

HILDA (Humana) Hilst (2002). Campinas: Unicamp. Documentário.

HILST, Hilda (1993). A obscena senhora D. Campinas: Pontes.

HILST, Hilda (2003). Fluxo floema. São Paulo: Globo.

HILST, Hilda (2005). Poemas malditos, gozosos e devotos. São Paulo: Globo.

HILST, Hilda (2016). Cartas de um sedutor. São Paulo: Globo.

HILST, Hilda (2016). O caderno rosa de Lori Lamby. In: HILST, Hilda. Pornochic. São Paulo: Globo.

LAWRENCE, David Herbert (1984). Pornografia e obscenidade. Tradução de Aníbal Fernandes. Lisboa: Etc.

NIETZSCHE, Friedrich (1998). Assim falou Zaratustra. Rio de Janeiro: Civilização Brasileira.

PÉCORA, Alcir (2010). Por que ler Hilda Hilst? São Paulo: Globo.

PURCENO, Sonia (2010). Ensaio de leitura In: PÉCORA, Alcir. Por que ler Hilda Hilst? São Paulo: Globo.

RIBEIRO, Leo Gilson (1999). Da ficção. In: FRANCESCHI, Antônio Fernando de (Org.). Cadernos de literatura brasileira - Hilda Hilst. São Paulo: IMS.

SCHØLLHAMMER, Karl Erik (2007). Além do visível: o olhar da literatura. Rio de Janeiro: 7Letras. 
SURYA, Michel (1994). O coice do burro. Prefácio. In: BATAILLE, Georges. A mutilação sacrificial e a orelha cortada de Van Gogh. Tradução de Carlos Valente. Lisboa: Hiena.

WERNECK, Humberto (1990/2016). Perfil. In: HILST, Hilda. Pornochic. São Paulo: Globo.

Recebido em 30 de agosto de 2016.

Aprovado em 31 de maio de 2017.

\section{resumo/abstract/resumen}

\section{O sol ofuscante de Hilda Hilst e Georges Bataille}

Aline Leal Fernandes Barbosa

Hilda Hilst e Georges Bataille foram autores que desafiaram constantemente os limites éticos e estéticos em seu fazer literário. Neste artigo, tomando a imagem do sol - cara a Bataille -, que tem em si a ideia da transgressão e do interdito, queremos pensar em que medida a atividade literária oscila entre romper os pactos socialmente impostos e preservá-los na medida de sua responsabilidade para com o leitor. No limite, esta ética vertiginosa do escritor estaria de acordo com a experiência do impossível, proposta por Bataille.

Palavras-chave: transgressão, interdito, impossível, ética.

\section{The burning sun of Hilda Hilst and Georges Bataille}

Aline Leal Fernandes Barbosa

Hilda Hilst and Georges Bataille were authors who constantly challenged the ethical and aesthetic limits in their literary work. In this article, by means of the image of the sun - which has in it the idea of transgression and interdiction - we want to think in which sense the literary activity oscillates between breaking the socially imposed covenants and preserving them as a responsibility to the reader. Ultimately, this vertiginous ethic would line up with the experience of the impossible, proposed by Bataille.

Keywords: transgression, interdiction, impossible, ethics. 


\section{El sol cegador de Hilda Hilst y Georges Bataille}

Aline Leal Fernandes Barbosa

Hilda Hilst y Georges Bataille fueron autores que desafiaron constantemente los límites éticos y estéticos en su composición literaria. En este artículo, tomando la imagen del sol - cara a Bataille - que tiene en él la idea de transgresión e interdicción, pensamos en qué medida la actividad literaria oscila entre romper los pactos impuestos por la sociedad y preservarlos en la medida de su responsabilidad con el lector. En última instancia, esta ética vertiginosa del escritor estaría en línea con la experiencia de lo imposible, propuesta por Bataille.

Palabras clave: transgresión, interdicción, imposible, ética. 